\title{
The Role and Perceptions of Middle Managers and Their Influence on Business Performance: The Case of Sri Lanka
}

\author{
Sriya Kumarasinghe (Corresponding author) \\ Department of Accountancy \& Business Law, University of Otago \\ PO Box 56, Dunedin 9054, New Zealand \\ Tel: 64-3-479-8120 E-mail: sriya.kumarasinghe@otago.ac.nz
}

Yasuo Hoshino

Graduate School of Accounting, Aichi University \& University of Tsukuba

2-10-31, Tsutsui, Higashi-ku, Nagoya 461-8641, Japan

E-mail: hoshino@aichi-u.ac.jp

An earlier version of this paper was presented at the Colloquium on Performance Management on $12^{\text {th }}$ Dec. 2007 at the University of Otago in New Zealand. The authors wish to thank the participants of the conference for their constructive comments.

\begin{abstract}
This paper investigates the role and perceptions of middle managers and how they influence business performance in Sri Lankan companies. The study presented here is based on a questionnaire survey of 121 middle managers regarding issues of communication, group decision making, and organizational leadership. Quantitative analysis of the responses suggests that organizations with collectivistic leaders achieve better performance. As a result, it is argued that collectivism, which includes middle management, can positively contribute to Sri Lanka's business development and economic recovery.
\end{abstract}

Keywords: Communication, Group decision making, Performance, Collectivism, Individualism, Leadership, Middle managers, Sri Lanka

\section{Introduction}

Business organizations face considerable challenges in the face of rapid technological development and global economic change. In Sri Lanka, these challenges have been heightened by the 30 year long civil war that ended in 2009 and the tsunami disaster of 2004. As an emerging economy, a key issue facing the country is to develop business models that can effectively respond to these challenges. Innovative, efficient and sustainable utilization of resources are intrinsic to long term planning and strategy. To this end, top management, middle management and employees need to work as an integrated team. This paper argues that the role of the middle managers is vital in this regard, since they are the link between senior management and employees, and also front line communicators who can readily complement leadership.

Research on organizational behaviour traditionally casts the CEO as the most influential change agent in the business environment (Chung \& Lo, 2007; Beugre et al., 2006; Caldwell, 2003; Grant \& Cibin, 1996). However, the view that management and leadership are synonymous has been criticized, since they perform two different roles. (Caldwell, 2003; Zaleznik, 1990). Leadership extends beyond the knowledge of management processes. Managers tend to focus on processes while leaders focus on imaginative ideas. Leaders not only dream up ideas, but stimulate and drive other people to work hard and create reality out of ideas (Zaleznik, 1990). Research on the role of middle managers is limited, despite their function in linking top management and employees. In some cases, interviews with employees have revealed that their CEOs meant nothing to them, because it is the middle managers who are the heroes in their eyes (Brubakk \& Wilkinson, 1996). The middle managers proximity to the employees and opportunity to identify conflicts and problems, as well as decoding corporate messages for employees play a key role in managing change and contributing to the organization's desired goals. However, when the necessary power and tasks are removed from middle managers or when they perceive the top leadership negatively, there is some evidence to suggest that middle managers become reluctant managers $(\mathrm{Wu}$ et al., 2007). Building team work, knowledge and consciousness of organizational goals depends on how middle managers perceive their leaders and their strategic visions. 
The roles played by middle and lower levels of management tend to be neglected in the literature on corporate culture. But how do the middle managers perceive their leaders? Does this perception make any difference to the bottom-line? Answers to these questions should be of interest to the management of any organization. This type of research is crucial for multinational companies in developing countries due to their cultural diversity of external and internal environment, and also due to their ability to attract foreign investors. With increasing international economic activities and globalization of markets, questions are raised about the effective application of western management and leadership techniques in emerging markets (Walumbwa \& Lawler, 2003). When western multinational companies (MNCs) move towards Asia seeking competitive advantage, is it possible for their expatriates to carry their familiar and well-established management practices with them to? What are the challenges to be met as a consequence? As an emerging economy, the case of Sri Lanka is worth consideration.

The economy of Sri Lanka has gone through a massive reformation since the liberalization of trade in 1977. Sri Lanka has now classified (together with Chile, Argentina, and Uruguay) as one of only four countries outside East Asia that has achieved a clear policy shift from import substitution-based industrialization to export-oriented industrialization (Athukorala \& Rajapatirana, 2000). To respond to this change, there has been substantial foreign investment in Sri Lanka and many new business ventures have appeared in the domestic business arena. The share of foreign direct investments in local industries has increased in dramatically. In 1977, the share of foreign firms in the export manufacturing sector was $24 \%$. By the mid 90 's, it managed to increase the share up to $80 \%$ (Athukorala \& Rajapatirana, 2000). Today Sri Lanka is gaining high popularity from the developed world for its skilled but cheap labour market and also for its attractive tax policies.

Apart from the world-wide attention Sri Lanka received at the time of the tsunami disaster in December 2004, the country remains little explored in the scholarly world of management. While some research has been published in this context (Kumarasinghe \& Hoshino, 2003; Chandrakumara \& Sparrow, 2004; Mamman et al., 2006; Akuratiyagamage, 2007), and to the best of our knowledge, there is little or no research that has focussed on middle-management's perceptions of leadership, or on management practices and organizational performance in Sri Lanka. It is this gap in the literature that this paper seeks to fill.

The work presented here is intended to assist top management and CEOs to understand the importance of having middle managers perceive them positively, as well as their influence on management processes, which in turn have a direct effect on the overall performance of the company. It can also contribute to company performance by improving quality and innovation,.

In what follows, we will discuss (i) previous research about middle managers' perceptions on leadership styles, communication and decision making, (ii) the methods used to investigate these issues and (iii) the results of the questionnaire survey that was sent to a sample of middle managers in Sri Lanka will be analysed and discussed. The limitations of the current study and potential future research are presented by way of conclusion.

\section{Literature Review}

In this section, the concept of leadership and the evolution of different leadership styles are briefly discussed, and the literature on leadership in cross-cultural context is reviewed. A research framework is developed and hypotheses are derived based on this review.

\subsection{Leadership}

Research on leadership covers the past several decades (Schmid, 2006; Oshagbemi \& Ocholi, 2006; Buus \& Saslow, 2005; Rodsutti \& Swierczek, 2002). Leadership is defined in many ways. It is variously viewed as a focus of group processes, personality and its effects, the art of inducing compliance, the exercise of influence, an act or behaviour, a form of persuasion, power relation, an instrument of goal achievement, an emerging effect of interaction, a differentiated role, the initiation of structure, or as a combination of elements (Bass, 1990).

Weber identified three types of leadership; rational-legal, traditional, and charismatic; based on the nature of power and authority they enjoy (Weber, 1947). According to Keith Davis, it was the ability to persuade others to seek defined objectives enthusiastically; the human factor that binds a group together and motivates it toward goals; and the ultimate act that brings to success all the potential that is in an organization and its people (Davis, 1977).

White and Lippitt (1960) focus on authoritarian, democratic, and laissez-faire styles of leadership to describe the general approach used by the leaders in human situations. Bass describes transactional and transformational styled of leadership. In transactional leadership style, the leader influences followers through desired rewards, and under transformational leaders, the followers are transformed through intellectual stimulation and higher 
level of motivation (Bass, 1985). Yang et al (2010) investigate the relationship between middle managers' transformational leaders and the performance of front line employees and confirm the existence of influence of middle managers on front line employees, bypassing their immediate supervisors, and also the existence of the moderating effect of the supervisors' power distance value. Hancer et al (2009) analyze the relationship between middle-level managers' personal risk-taking propensities and corporate entrepreneurship among 106 middle-level hotel managers in Turkey. Since none of the risk factors which included profit risk, emotion risk, managerial risk, or venue risk influenced corporate entrepreneurship, they suggest that middle managers must have the support of top management for risk taking along with a reasonable tolerance for failure.

The research carried out by $\mathrm{Wu}$ et al. (2007) was an attempt to identify the influence of the immediate supervisor's transformational leadership on employees' cynical attitudes towards organizational changes in the Chinese context. They concluded that transformational leadership was negatively related to employee cynicism about organizational change and that this relationship was mediated by employees' informational and interpersonal justice perceptions. The relationship was enhanced when employees perceived their work group as cohesive.

\subsection{Collectivism and Individualism}

The influence of national culture in organizational settings has been brought to light by Hofstede (1980) in his work on national cultures, and it has broadened the arena of organizational research substantially (Ramamoorthy et al. 2007). Even though his research was heavily criticised in the later years (Bakersville, 2003), his work has been strengthened by the global study of House et al., (2004) and is still used extensively.

According to Hofstede's research, some less individualistic countries are less developed in terms of their economic growth. Those societies respect tradition and collective thinking. One of the key characteristic of individualistic and collectivistic values is the emphasis placed on the individual goals versus collective goals. Individualists put more weight on self-interest, personal goals and personal achievements. Collectivists place group goals ahead of the individual goals. Collectivistic societies are characterized with large power distance, inter-dependence on the group members, extended family relations, high communication and group decision making (Hofstede, 1991). If we match this conceptualization with the traditional values in Sri Lanka, Sri Lanka can be viewed as a member of the collectivistic group of countries.

Walumbwa et al. (2003) have investigated the moderating impact of collectivism on the relationship between transformational leadership behaviour, collectivism, work-related attitudes, and perceptions of organizational withdrawal behaviour in China, India, and Kenya. Their research reveals a moderating effect of collectivism on the relationship between transformational leadership and work-related outcomes, such as facets of job satisfaction, organizational commitment, and perceptions of organizational withdrawal behaviours. Contrary to their expectations, transformational leadership explained a greater proportion of variance in all outcome measures under low, medium and high collectivism. The authors believe that transformational leaders pay special attention to each individual's abilities, aspirations and needs to enhance their confidence in facing challenges in their work. Ramamoorthy et.al. (2007) report that Indian employees were slightly but significantly less individualistic than Irish employees on supremacy of individual goals and on solitary work preferences, but on competitiveness, Indian employees were more individualistic than Irish workers (Ramamoorthy et.al. 2007).

Freeman's research on individualism and collectivism in Sri Lanka concludes by saying that some conditions of individualism and collectivism are likely to differ across different social groups categorized on their location of residence, socioeconomic status, educational level, and occupational status (Freeman, 1997). It forecasts that with the continued expansion of urban industrial development and rising incomes, there will be a shift towards individualism in Sri Lanka. This work supports a previous research finding in which individualism is seen as a behavioural characteristic in middle and higher executive levels (Nanayakkara, 1988). The contrasting results reported from these environments clearly requires empirical research.

\subsection{Middle Managers}

Middle managers have traditionally been seen as suppliers of information and the consumers of decisions made by the top-level managers, in their business organizations (Thompson, 1967). The object of the communication system is coordination of all aspects of the organization (Barnard, 1938). Instead of top-down or bottom-up models, some researchers have paid attention to the "middle-up-down" approach emphasizing the "knowledge creation' by the middle managers. Middle managers are synonymous with "backwardness", "stagnation" and "resistance to change" but they are the key to continuous innovation (Nonaka \& Takeuchi, 1995). In the process of knowledge creation, employees, especially the middle managers, play an important role building up a new 
organization structure and transforming knowledge between the traditional hierarchical system and project teams (Nonaka \& Takeuchi, 1997).

Middle managers are in a strong position to introduce organizational change. Foreseeing turbulent times ahead, Peter Drucker said, the very term 'middle management' is becoming meaningless in the context of what he called as the 'double-headed monster' (Drucker, 1980). Drucker emphasizes the important role of middle managers in creating and maintaining effective management systems. Upward influence is commonly associated with consensus decisions, commitment to goals, and innovation (Schilit, 1987). This view is confirmed by many scholars including Nonaka \& Takeuchi (1995). During the last decade Japanese companies have undergone major changes. Many of them have downsized and middle managers have been burdened with extra responsibilities and the stress of uncertainty concerning their jobs (Iida \& Morris, 2008) Shedding a new light on the symptoms of organizational problems at middle management level in Japanese companies, Karube et al (2009) postulated that extra organizational load is prevalent in deteriorating organizations. They further claim that rigid conformity and excessive emphasis on harmony may make it difficult for middle managers to realize new strategic initiatives.

\subsection{Communication}

Communication and inter-personal relationships are closely related to organizational factors which lead to job satisfaction and better performance (Jo \& Shim, 2005), which eventually leads to better overall performance in organizations. Therefore effective communication is vital at every level to ensure smooth running of the organization (Brownell, 1991). As Jo and Shim (2005) demonstrate, supportive oral communication was positively related to the perceptions of the individuals on supportiveness and friendliness of the management. They found that managers who communicate well and attentively to their subordinates achieve better results in situations that involve nurturing and maintaining trustworthy relationships. Neelankavil et al. (2000) conducted cross-cultural comparative research on the perceptions of middle-level managers and performance in China, India, Philippines and United States. They found culture has a significant impact on managerial practices particularly between China and the United States. Further they found significant differences among managers of the three Asian countries as compared with US. Their findings show that while Chinese and American middle managers represented two extreme leadership styles of individualism and collectivism. In communication and decision making, Filipino and Indian managers were found much similar to US than Chinese counterparts. Addressing the issue of corporate social responsibility (CSR) in small- and medium-sized enterprises (SMEs), Nielsen and Thomsen (2009) conducted a case study interviewing three middle managers in two firms in Denmark. They concluded that in order to develop corporate identity and image of the firms as good corporate citizens, SMEs need to strengthen both direct and indirect communication.

Highlighting the importance of middle managers, Robbins (1983) points out tall organizations reduce the power of top management, because middle managers gain control over the information. Since middle managers know more about what is going on at the operational level, they also can filter out information before passing it up to the top management. Westley (1990) emphasizes the dissatisfaction among middle managers who often perceive as they are excluded from the strategic process. He concludes that the top management should pay attention to the conditions wherein middle managers are likely to experience exclusion, inclusion, and sustained energy on strategic issues. Middle managers feel exclusion when there is resisted conversation, lack of formal or informal mechanisms to allow middle managers to communicate cross-functionally, or when general strategic discussions are limited to top status group. Consequently, top management should address the 'exclusion and inclusion' issues strategically and tactfully to convert the relationships with middle managers into positive relationships in order to gain better long-term results.

\subsection{Decision Making}

Research on upward influence in decision making has received little attention (Schilit, 1987). The results of research by Schilit confirms that middle level managers' influence on upward strategic decisions, both high-risk and low-risk decisions, led to greater incidents of success than failure. Those decisions were however more prevalent in private organizations than public organizations. Middle level managers who had longer work experience with their senior managers had also been seen as the key influencers in strategic decision making by creating and building mutual trust.

The following three hypotheses are derived from the research presented above.

Hypothesis 1. Communication and group decision making has a significant influence on organizational performance. 
Hypothesis 2. Communication systems are more effective in business organizations where middle managers perceive their leaders as more collectivistic, and have significant positive influence on performance.

Hypothesis 3. In business organizations where middle managers perceive their leaders as more collectivistic, with greater emphasis on group decision making, this will have significant positive influence on performance.

\section{Methods}

\subsection{Survey method}

A structured questionnaire was the main instrument used in this study. In the view of many experienced researchers, structured questions produce more relevant and comparable responses than open-end ones (Rosenthal \& Rosnow, 1991). The questions were developed using the Likert Model of Item Analysis, and used only four scales in order to avoid indifferent answers, or selecting the middle scale for convenience. The four scales were 'strongly agree, agree, disagree, and strongly disagree'. The questionnaire was reviewed by professionals and practitioners and pre-tested by administering it to 25 managers who were the participants of an executive program in a leading university in Sri Lanka.

\subsection{Sample}

The sample was randomly selected from businesses functioning in the Greater Colombo area. A total of 200 questionnaires were distributed with the permission of the chairman or the director of the companies. Questionnaires were handed out to companies to be completed by a manager under the CEO in each company. A cover letter with each questionnaire, promised all participants strict anonymity. Telephone calls were made to act as reminders and provide notification before collection. A 121 questionnaires were completed and returned constituting a response rate of 60.5 percent. Of these, 66 companies were registered on the Colombo Stock Exchange. Four companies in the sample were fully decentralized plants or profit centres of multi-business companies. Twenty-seven companies had not declared their company name or other contact details in the questionnaire. Therefore they were not in the company list.

Financial performance data were obtained from published annual reports; consequently the use of quantitative performance analysis was limited to the listed companies in the sample.

\subsection{Organizational factors}

Key variables were selected for the organizational attributes of leadership (Hater \& Bass, 1988; Neelankavil et al., 2000; Xenikou \& Simosi, 2006), communication (Robbins, 1983; Hater \& Bass, 1988; Brownell, 1991; Neelankavil et al., 2000; Hofstede, 2001, Jo \& Shim, 2005), and group decision making (Burns \& Stalker, 1961; Keller et al., 1974; Hofstede, 1980; Robbins, 1983; Hater \& Bass, 1988; Neelankavil et al., 2000). Both communication and group decision making have been identified as crucial factors in establishing healthier relationship between leaders and middle managers.

Variables for the analysis were derived by calculating average mean values of several variables under each attribute. To distinguish leadership style as collectivistic or individualistic, average mean value of three variables, superior's control over subordinate's work, superior's concern on subordinate's personal problems, and subordinate willingness to talk openly and frankly with the superior was used. The median value for the leadership was 2.66. The organizations which have above median value for leadership were categorised as collectivistic and below median values were considered as individualistic. The value used for communication was the average mean of three variables; speed of top bottom, bottom up, and horizontal communication $($ Cronbach Alpha $=.564)$. Group decision making $(\mathrm{GDM})$ was the average mean of five variables; GDM for corporate objectives, GDM for functional objectives, GDM for new technology and development, GDM for transfer and promotions, and GDM for reward system planning (Cronbach Alpha $=.887$ ).

\subsection{Performance measures}

Measuring performance is a controversial issue in management studies. Some researchers focus only on financial measures and some argue about the necessity of both qualitative and quantitative measures. Robson et al. (2006) reviewed the empirical studies on behavioural attributes and performance in international strategic alliances. They identified three distinct performance measurement approaches; multifaceted assessment, financial assessment and stability measurement. Among the 41 studies they reviewed, multivariate performance indicators were used in 32 studies. Multifaceted assessments are based upon managers' perceptual judgements in terms of self-rate performance, giving an overall viewpoint on satisfaction with performance or goal achievement. The method of multiple assessments stands over the single-facet performance measures which may not adequately capture the achievement of the objectives. Even though the balanced scorecard measuring system (Kaplan \& 
Norton, 1992; Adler \& Theivananthampillai, 2006) is considered as a more successive extension of the multifaceted assessment, wide use of financial or economic performance measures such as return on equity (ROE) (Mak \& Akhtar, 2003), return on assets (ROA), return on sales (ROS) (Goll \& Sambharya, 1998), return on investment (ROI), sales growth rate (SGR), profit growth rate (PGR) (Kumarasinghe \& Hoshino, 2003) are still commonly used.

The Japanese way of pursuing excellence is called KAIZEN, or a system of continuous improvement. Whereas western management rates innovation and dramatic breakthroughs or production techniques very highly, KAIZEN or continuing improvement system is undramatic and subtle by way of comparison (Imai, 1991). The KAIZEN system and Total Quality Control (TQC) have a very strong connection. TQC typically deals with areas such as quality assurance, cost control, collectivism and team work, meeting production and delivery schedules, safety, new product development, productivity improvement, and supplier management. The benefits of KAIZEN can thrive only under a top management that has genuine concern for the long-term health of the company (Imai, 1991). Paladino (2007) investigated the market orientation and resource based view of firms for innovation, new product success, financial performance, market share, and customer value. Findings showed that organizational learning was strongly associated with market orientation, which in turn impacts various performance outcomes. The resource based view also had a significant relationship with new product success. Paladino states that innovation had an indirect effect on customer value and financial performance.

Based of these quantitative and qualitative interpretations on performance, ROI, net profit growth, and average sales growth were used for this study as quantitative measures of performance (Marcoulides \& Heck, 1993). As qualitative measures of performance, quality, service, innovation, new idea proposals, and employee satisfaction were used (Miles \& Snow, 1978; Delery \& Doty, 1996; Liouville \& Bayad, 1998; Ahmed et al, 1998; Mak \& Akhtar, 2003; Prajogo \& Sohal, 2006; Paladino, 2007). The indicator of quality was the average mean of five items, product quality, waste control, quality of equipment and technology, quality of personnel, and quality of training and development (Cronbach Alpha $=.714)$. Service included the average means of two variables, supplier and customer service (Cronbach Alpha $=.582$ ). Innovation consisted of the average means of three variables; creativity and innovativeness of products, processes, and marketing (Cronbach Alpha $=.811)$. New idea proposal was the average mean of two variables; introduction of new products and frequent proposals of new methods and new ideas (Cronbach Alpha $=.551$ ).

The groups of variables in the constructs of communication, service and new idea proposals had lower alpha coefficients than the normally accepted level. Some researchers are rigid about this 'acceptable level' and some are cautious about the deletion of possible important information merely for the purpose of reaching the acceptable alpha level (Spiliotopoulou, 2009). Spiliotopoulou claims that low size of the coefficient alpha might not always suggest adequate reliability. Low level of alpha might be related to the limited number of items included in the test, or due to the limited width of the scale which may be the cause behind the low alpha coefficient in some of our variables. Schmitt states that satisfactory levels of alpha depend on test use and interpretation. Even relatively lower (e.g. .50) levels of criterion reliability do not seriously attenuate validity coefficients (Schmitt (1996). Therefore we decided to continue with low alpha for some of the variables in the analysis. The need for further improvement of the data set was noted. Employee satisfaction was measured by only one variable. The data were normally distributed (skewness was less than 0.4 ) with low or no correlation.

\section{Results}

Table 1 shows descriptive statistics of the behavioural factors and performance variables in the total sample of 121 business organizations.

Eighty one organizations were categorized as having collectivistic leadership and 26 organizations with an individualistic leadership approach. Among the 66 organizations, there were 41 companies with collectivistic leaders and 25 companies with individualistic leaders. Compared to the mean values in individualistic companies, collectivistic companies scored higher values in all behavioural and qualitative performance factors except in quantitative measures of the net profit growth and average sales growth.

The regression results in the tables from 3 to 8 show the influence of communication and group decision making on performance measures and also the differences among the two types of organizations in which middle managers perceive their leaders differently. The sample was tested against multicollinearity and the values were within the tolerance range.

With regards to the total sample of 121 companies, Table 2 shows that both attributes of faster three-way communication and group decision making made significant positive influence on quality, service, and innovation. Group decision making had a relatively lower but a significant and positive influence on new idea 
proposals and employee satisfaction. When the model was applied separately for the companies with collectivistic and individualistic leaders, significant correlations were found in the collectivistic group. Within collectivism, group decision making was a significant factor for quality, service, innovation, and employee satisfaction. Communication had only a lower level of influence on innovation but no influence on other measures (Table 3). The organizations functioned under individualistic leadership, communication or group decision making were not good predictors of qualitative performance in those companies (Table 4).

When the regression model was run to see the nature of the relationship between behavioural factors and quantitative performance measures, the results were rather opposite. In the sample of 66 companies, in which the quantitative financial data was available, we could see communication as a significant factor but having a negative influence on ROI. Group decision making had a positive influence and the model was significant. Profit growth or sales growth did not show significant results (Table 5).

In the collectivistic group, the profit growth and ROI were positively and significantly influenced by group decision making. The model for ROI was significant (Table 6). Communication had a significant negative influence on ROI, and not significant with profit growth or sales growth. Under individualistic leadership, there was no significant result between quantitative performance factors and behavioural factors (Table 7).

\section{Discussion}

All the hypotheses were supported except for quantitative performance measures. As we hypothesized in H1, both communication and decision making showed a significant and positive influence on qualitative performance measures. In the case of quantitative measures, our prediction was partially supported. Group decision making showed significant and positive influence on ROI but communication had a negative influence. The results from the total sample suggested that more group decision making but less multi-directional communication were good predictors of company's ROI. In the group of companies with collectivistic leaders, much stronger results were derived (H2). In those organizations both communication and group decision making had strong influence on both qualitative and quantitative measures except between communication and quantitative measures. Under individualistic leadership condition (H3), there were no significant relationships between communication and/or group decision making, and qualitative or quantitative performance measures.

These results raise the need to explore why the sample organizations in Sri Lanka did not impact on quantitative measures such as profit, sales or ROI, while there was evidence of the existence of 'so-called' better management practices that could lead to financial success as described in western management concepts.

The results were consistent with the empirical research findings by Niles (1999). Niles showed that Australians who carry the western work ethics scored highest on outcomes of hard work and lowest on self reliance, while the Sri Lankans who represent Buddhist or eastern work ethics scored highest on self-reliance and lowest on outcomes. His study suggests that Sri Lankans endorse a work ethic defined as 'respect for, admiration of, and willingness to take part in hard work' more strongly than people from the western cultures. Niles also recognized Sri Lanka as a collectivistic country, and concludes by saying that most religions and most cultures seem to have a common concept of work ethic; defined as a commitment to hard work and to excellence. However, what does not seems to be universal is a direct relationship between hard work and success. There could be a religious influence which emphasizes individual responsibility. Niles says that Sri Lankans have the right ingredients for economic success, but motivation and the right attitudes are only one part of the factors leading to the economic development. The question that arises here is "What is the religious influence in the Buddhist culture of Sri Lanka which restricts business development and financial success?"

Research on the influence of religion in decision making (Fernando \& Jackson, 2006) reveals that the religion plays a significant role in influencing the judgement, emotional and motivational qualities of Sri Lankan leaders' decision making. Ancient Sinhala texts of Theravada Buddhism explain how persons are expected to react when they read or listen to a recital of its narrative. Events of the past have had a direct and significant impact upon their present lives and future destiny. In the Buddhist society of Ceylon (now Sri Lanka) bhikkhus (monks) who preached the Buddhist way of living performed as teachers and advisors of the community (Rahula, 1966) and that practice remains the same even today. Organizations like Sarvodaya in Sri Lanka continuously apply Buddhist philosophy and show how positive results can be achieved by effective decision making in a collectivist environment.

Buddhist perspectives on employer-employee relationships are worth careful consideration. According to the Sigalovada Sutta which contains the Buddha's teachings on domestic and social duties, there are five ways in which a master should minister to his servants and work people: by assigning them work according to their strength; by supplying them with food and wages; by tending them in sickness; by sharing with them any profits; 
and by granting leave and special allowances. Similarly, there are five ways in which employees ministered to by their master: they rise before him, they lie down to rest after him; they are content with what is given to them; they do their work well; and they carry about his praise and good fame (de Silva, 1974). The master described here is a person who has more collectivistic values, and the employee is a hard-working man. In the Parabhava Sutta, another part of the Buddha's teachings, the Buddha teaches that people who are rich lay people should support their elderly parents, but wealth alone should not be promoted. Such practices are likely to affect one's success in life. Wealth itself or the accumulation of wealth negatively perceived in Theravada Buddhism, which dominates Sri Lankan society. Theravada Buddhism differs from Mahayana Buddhism, which is commonly practiced in Japan, Korea, and China. Wealth sharing is a widely used traditional motto in Sri Lanka.

Collectivistic leadership promotes qualitative measures which may lead to more sustainable economic performance in the long-run through qualitative achievements. The Xenikou and Simosi (2006) suggest that a humanistic orientation places significant but negative direct impact on financial performance. Our findings are consistent with this conclusion.

Although there was no positive relationship between behavioural attributes and quantitative performance factors, it is worth noting that tax avoidance and lack of policy implementation towards efficiency are also common in developing economies like Sri Lanka.

\section{Conclusion}

The aim of the present study was to investigate whether middle managers' perceptions on their leaders are related to communication and decision making processes and influence performance. Organizational behavioural attributes were analysed against both qualitative and quantitative performance indicators.

Our findings show that in organizations in which middle managers perceive their leaders as collectivistic, group decision making and fast two-way communication were commonly in practice, and this contributed to high quality, better service, innovation, new idea proposals and employee satisfaction. Interestingly, under collectivistic leadership, communication or decision making did not influence economic performance. There may be an influence of religion for that result and it needs further investigations.

We suggest in conclusion that CEOs and managers of companies operating in Sri Lanka should consider cultural values and religious beliefs when setting economic goals for the organization. They should also allow for group decision making and remove barriers that impede fast and two-way communication.

Limitations of the research include the use of a single-respondent. Collinearity was not tested. Analysis of quantitative measures of performance was limited to those companies which have published their financial information, accounting for over half of the total sample. Future studies require wider sampling and comparative data drawn from other Asian countries.

Business models that have been applied to Sri Lanka to date are largely based on western ideologies. However, Sri Lanka is a unique environment with a unique history and cultural mix. This uniqueness and its impact on business development needs to carefully considered and needs to be part of a much larger research agenda. We look forward to contributing towards this agenda in the future.

\section{Acknowledgement}

This study has been partly conducted with the assistance of "Grant-in-Aid for Scientific research from Japan Society for the Promotion of Science".

We also acknowledge Dr. Graham McGregor, School of Business, University of Otago for his useful comments on this paper.

\section{References}

Adler, R. W. \& Theivananthampillai, P. (2006). Strategic Investment Proposals and the Balanced Scorecard: How to Ensure Consistency Between investments and Long Term Strategy. Asia-Pacific Management Accounting Journal, 1(1), 113-125.

Ahmed, N. U., Montagno, R. V. and Firenze, R. J. (1998). Organizational Performance and Environmental Consciousness: An Empirical Study, Management Decision, 36 (2), 57-62.

Akuratiyagamage, V. M. (2007). Management Development Practices; Empirical Evidence from Sri Lanka, The International Journal of Human Resource Management, 17 (9), 1606-1624.

Athukorala, P. \& Rajapatirana, S. (2000). Liberalization and Industrial Transformation: lessons from the Sri Lankan Experience, Economic Development and Cultural Change, 48(3). 543-572. 
Bakersville, R. F. (2003). Hofstede Never Studied Culture, Accounting, Organizations and Society, 28, 1-14.

Barnard, C. I., (1938). The Functions of the Executive, Cambridge: Harvard University Press.

Bass, B.M. (1990). Bass \& Stogdill's Handbook of Leadership: Theory, Research \& Management Applications, Third Ed. New York, Free Press.

Bass, B.M. (1985). Leadership and Performance Beyond Expectations, New York, Free Press.

Beugre, C. D., Acar, W. \& Braun, W. (2006). Transformational Leadership in Organizations: an Environment-induced Model, International Journal of Manpower, 27(1), 52-62.

Brownell, J. (1991). Middle Managers: facing the communication Challenge, Cornell Hotel and Restaurant Administration Quarterly, 31(4), 52-59.

Brubakk, B. \& Wilkinson, A. (1996). Agents of Change? Bank Branch Managers and the Management of Corporate Culture Change, International Journal of Service Industry Management, 7 (2), 21-43.

Burns, T. \& Stalker, G. M. (1961). The Management of Innovation, London, Tavistock.

Buus, I. \& Saslow, S. (2005). The Evolution of Leadership Development, Strategic HR Review, 4(2), 28-31

Caldwell, R. (2003). Change Leaders and Change Managers: Different or complementary? Leadership and Organization Development Journal, 24(5), 285-293.

Chandrakumara, A. \& Sparrow, P. (2004). Work Orientation as an Element of National Culture and its Impact on HRM Policy-Practice Design Choices, International Journal of Manpower, 25 (6), 564- 589.

Chung, Ruey-Gwo \& Lo, Chieh-Ling. (2007). The Relationship between leadership Behaviour and Organizational Performance in Non-Profit Organizations, using Social Welfare Charity Foundations as an Example, Journal of American Academy of Business, 12 (1), 83-87.

Davis, Keith (1977). Human Behaviour at Work, $5^{\text {th }}$ ed., New York, McGraw-Hill Book Company.

Delery, J. E. \& Doty, D. H., (1996). Modes of Theorizing in Strategic Human Resource Management: Tests of Universalistic, Contingency, and Configurational Performance Predictions, Academy of Management Journal, 39(4), 802-835.

De Silva, L. A. (1974). Buddhism: Beliefs and Practices in Sri Lanka, Colombo, Wesley Press.

Drucker, P. (1980), Managing In Turbulent Times, Oxford: Butterworth-Heinemann Ltd.

Fernando, M. \& Jackson, B. (2006). The Influence of Religion-based Workplace Spirituality on Business Leaders' Decision Making: An Inter-faith Study, Journal of Management and Organization, 12(1) 23-39.

Freeman, M.A. (1997). Demographic Correlates of Individualism and Collectivism: a study of Social Values in Sri Lanka, Journal of Cross-Cultural Psychology, 28(3) May.

Goll, I. \& Sambharya, R. B. (1998). Rational Model of Decision making, Strategy, and Firm Performance, Scandinavian Journal of Management, 14 (4), 479-492.

Grant, R. M. \& Cibin, R. (1996). The Chief Executive as Change Agent, Planning Review, 24(1), 9-11.

Hancer, M., Ozturk, A. B., \& Ayyildiz, T. (2009). Middle-Level Hotel Managers' Corporate Entrepreneurial Behaviour and Risk-Taking Propencities: A Case of Didim, Turkey, Journal of Hospitality Marketing \& Management, 18, 523-537.

Hater, J. J. \& Bass, B. M. (1988). Journal of Applied Psychology, 77 (4), 695-702.

Hofstede, G., (2001), Culture's Consequences; Comparing Values, Behaviours, Institutions, and Organizations Across Nations, $2^{\text {nd }}$. Ed.,Thousand Oaks: Sage Publications.

Hofstede, G., (1991), Cultures and Organizations; Software of the Mind, London: McGraw-Hill.

Hofstede, G., (1980). Culture's Consequences; International Differences in Work-Related Values, (London: Sage Publications).

House, R. J., Hanges, P. J., Javidan, M., Dorfman, P. W., Gupta, V. (2004). Culture, Leadership and Organizations. The Global Study of 62 Societies, Thousand Oaks, Sage.

Iida, T. \& Morris, J. (2008). Farewell to the Salaryman? The Changing Roles and Work of Middle Managers in Japan, The International Journal of Human Resource Management, 19(6), 1072-1087.

Imai, M., (1991). KAIZEN - the Key to Japan's Competitive Success, Singapore, McGraw-Hill. 
Jo, S. \& Shim, S.W. (2005). Paradigm Shift of Employee Communication: The Effect of Management Communication on Trusting Relationships, Public Relations Review, 31, 277-280.

Kaplan, R. S. \& Norton, D. P. (1992). The Balanced Scorecard - Measures that Drive Performance. Harvard Business Review, Jan-Feb.71-79

Karube, M., Numagami, T. \& Kato, T. (2009) Exploring Organizational Deterioration: 'Organizational Deadweight' as a Cause of Malfunction of Strategic Initiatives in Japanese Firms, Long Range Planning, 42, pp. 518-544

Keller, R. T., Slocum JR, J. EW. and Susman, G. I., (1974). Uncertainty and Type of Management System in Continuous Process Organizations, Academy of Management Journal, Vol 7 (1), pp.56 - 68.

Kumarasinghe, S. \& Hoshino, Y. (2003). Influence of Corporate Culture, Structure and Strategy on Organizational Performance: An Empirical Study of Business Organizations in Sri Lanka. Japanese Journal of Administrative Science, 16(3), 227-242

Liouville, J., \& Bayad, M. (1998). Human Resource Management and Performance: Proposition and Test of a Causal Model, Human Systems Management, 17, 183-192

Mak, S. K.M. and Akhtar, S. (2003). Human Resource Management Practices, Strategic Orientations, and Company Performance: a Correlation Study of Publicly Listed Companies. The Journal of American Academy of Business, 2(2), 510-515

Mamman, A., Akuratiyagamage, V. W. and Rees, C. J. (2006). Managerial Perception of the Role of the Human Resource Function in Sri Lanka: A Comparative Study of Local, Foreign-Owned and Joint-Venture Companies. International Journal of Human Resource Management, 17(12), 2009-2020

Marcoulides, G. A. \& Heck, R. H. (1993). Organizational Culture and Performance: Proposing and Testing a Model, Organization Science, 4(2), 209-225.

Miles, R. E. \& Snow, C. C, (1978). Organizational Strategy, Structure, and Process, New York: McGraw-Hill

Nanayakkara, G. (1988). Culture and Management in Sri Lanka, Colombo, Sri Lanka Institute of Co-operative Management.

Neelankavil, J. P., Mathur, A., \& Zhang, Y. (2000). Determinants of Managerial Performance: A Cross- Cultural Comparison of the Perceptions of Middle-Level Managers in Four Countries, Journal of International Business Studies, 31(1), 121-140

Nielsen, A. E. \& Thomsen, C. (2009). CSR Communication in Small- and Medium-sized Enterprises: A Study of the Attitudes and Beliefs of Middle Managers, Corporate Communications, an International Journal, 14(2), 176-189.

Niles, F. S. (1999). Towards a Cross-Cultural Understanding of Work-Related beliefs, Human Relations, 52(7), 855-867.

Nonaka, I \& Takeuchi, H. (1997) A New Organizational Structure in Knowledge in Organizations, (Ed) Laurence Prusak, Butterworth-Heinemann, USA, pp 99-133

Nonaka, I. \& Takeuchi, H., (1995) The Knowledge Creating Company, (New York: Oxford University Press)

Oshagbemi, T. \& Ocholi, S. A. (2006). Leadership Styles and Behaviour Profiles of Managers, Journal of Management Development, 25(8), 748-762.

Paladino, A. (2007). Investigating the Drivers of Innovation and New Product Success: A Comparison of Strategic Orientations, The Journal of Product Innovation Management, 24, 534-553.

Prajogo, D. I. \& Sohal, A. S. (2006). The Relationship between Organization Strategy, Total Quality Management (TQM), and Organization Performance - The Mediating Role of TQM, European Journal of operational Research, 168, 35-50.

Rahula, Rev.Walpola. (1966) . History of Buddhism in Ceylon, Colombo, M.D.Gunasena \& Co. Ltd.

Ramamoorthy, N., Kulkarni, S. P., Gupta, A., \& Flood, P. C. (2007). Individualism-Collectivism Orientation and employee Attitudes: A comparison of Employees from the High-technology Sector in India and Ireland, Journal of International Management, 13, 187-203.

Robbins, S. P. (1983). The Theory Z Organization from a Power-Control Perspective, California Management Review, 25(2), 67-75. 
Robson, M. J., Skarmaes, D., \& Spyropoulou, S. (2006). Behavioural Attributes and Performance in International Strategic Alliances: Review and Future Directions. International Marketing Review, 23 (6), 585-609.

Rodsutti, M. C. \& Swierczek, F. W. (2002). Leadership and Organizational Effectiveness in Multinational Enterprises in Southeast Asia, Leadership \& Organization Development Journal, 23(5), 250-259

Rosenthal, R. \& Rosnow, R. L. (1991). Essentials of Behavioral Research: Methods and Data Analysis, Singapore: McGraw-Hill.

Schilit, W. K. (1987). An Examination of the Influence of Middle-Level Managers in Formulating and Implementing Strategic Decisions, Journal of Management Studies, 24(3), 271-293

Schmid, H. (2006). Leadership Styles \& Leadership Changes in Human \& Community Service Organizations, Nonprofit Management \& Leadership, 17(2), 179-194.

Schmitt, N. (1996). Uses and Abuses of Coefficient Alpha, Psychological Assessment, 8(4), 350-353.

Spiliotopoulou, G. (2009). Reliability Reconsidered: Cronbach Alpha and Paediatric Assessment in Occupational Therapy, Australian Occupational Therapy Journal, 56, 150-155.

Thompson, J., (1967), Organization in Action, (New York; McGraw_hill).

Walumbwa, F. O. \& Lawler, J. J. (2003). Building Effective Organizations: Transformational leadership, Collectivist Orientation, Work-related Attitudes and Withdrawal behaviours in Three Emerging Economies, International Journal of Human Resource management, 14 (7), 1083-1101.

Weber, Max. (1947). The Theory of Social and Economic Organizations, trans. by A.M. Henderson and Talcott Parsons, Oxford University Press, Fair Lawn, N.J.

Westley, F. R. (1990). Middle Managers and Strategy: Microdynamics of Inclusion, Strategic Management Journal, 11, 337-351

White, R. \& Lippitt, R. (1960). Autocracy and Democracy. Harper \& Row, New York.

Wu, C., Neubert, M.J., \& Yi, X., (2007), “Transformational Leadership, Cohesion Perceptions, and Employee Cynicism about Organizational Change; The Mediating Role of Justice Perceptions, The Journal of Applied Behavioural Science, Vol. 43 (3), pp. 327-351.

Xenikou, A. \& Simosi, M. (2006). Organizational Culture and Transformational Leadership as Predictors of Business Unit Performance, Journal of Managerial Psychology, 21 (6), 566-579

Yang, J, Zhang, Z, \& Tsui, A. S. (2010). Middle Manager Leadership and Frontline Employee Performance: Bypass, Cascading, and Moderating Effects, Journal of Management Studies, 47(4), 654-678

Zaleznik, A. (1990). The Leadership gap, The Executive, 4 (1), 7- 22

Table 1. Mean differences among organization groups

\begin{tabular}{|c|c|c|c|c|c|c|}
\hline \multirow{2}{*}{$\begin{array}{l}\text { Behavioural } \\
\text { factors }\end{array}$} & \multicolumn{2}{|c|}{$\begin{array}{l}\text { Total Sample* } \\
\mathrm{N}=121\end{array}$} & \multicolumn{2}{|c|}{$\begin{array}{l}\text { Collectivistic } \\
\mathrm{N}=81\end{array}$} & \multicolumn{2}{|c|}{$\begin{array}{l}\text { Individualistic } \\
\mathrm{N}=26\end{array}$} \\
\hline & Mean & SD & Mean & SD & Mean & $\mathrm{SD}$ \\
\hline leadership & 2.7913 & .49425 & 3.0000 & .32914 & 2.1410 & .32895 \\
\hline communication & 2.8836 & .58562 & 2.9600 & .60766 & 2.7067 & .49366 \\
\hline group decision making & 2.8078 & .74356 & 2.8907 & .72058 & 2.6273 & .73884 \\
\hline quality & 2.9965 & .51798 & 3.0240 & .52911 & 2.8692 & .34382 \\
\hline service & 3.1000 & .60408 & 3.1234 & .58577 & 2.9800 & .54924 \\
\hline innovation & 2.7788 & .68662 & 2.8248 & .67682 & 2.5972 & .64440 \\
\hline new idea proposals & 2.6942 & .71480 & 2.7368 & .69510 & 2.6667 & .76376 \\
\hline satisfaction & 2.8704 & .47543 & 2.9481 & .45584 & 2.6087 & .49901 \\
\hline profit growth & 381.285 & 1156.389 & 276.226 & 575.568 & 805.331 & 2241.835 \\
\hline average sales growth & 161.268 & 575.607 & 112.189 & 547.616 & 363.511 & 747.408 \\
\hline ROI & .1368 & .1045 & .1387 & .1154 & .1249 & .0891 \\
\hline
\end{tabular}

* For quantitative measures total $\mathrm{N}=66$, Collectivistic $\mathrm{N}=41$, Individualistic $\mathrm{N}=25$ 
Table2. Regression Results for Qualitative Performance Measures in the Total Sample ( $N=121)$

\begin{tabular}{|c|c|c|c|c|c|}
\hline Dependent Variables & Independent Variables In the Model & $\mathrm{B}$ & SEB & $\beta$ & t value \\
\hline Quality & $\begin{array}{l}\text { Communication } \\
\text { Group decision making } \\
\text { Constant } \\
\mathrm{R}^{2}=.345, \quad \mathrm{~F}=23.75^{* * *}\end{array}$ & $\begin{array}{l}.178 \\
.334 \\
1.550\end{array}$ & $\begin{array}{l}.083 \\
.067 \\
.236\end{array}$ & $\begin{array}{l}.204 \\
.470\end{array}$ & $\begin{array}{l}2.151 * * \\
4.963 * * * \\
6.563 * * *\end{array}$ \\
\hline Service & $\begin{array}{l}\text { Communication } \\
\text { Group decision making } \\
\text { Constant } \\
\mathrm{R}^{2}=.211, \mathrm{~F}=12.00^{* * *} \\
\end{array}$ & $\begin{array}{l}.181 \\
.280 \\
1.790\end{array}$ & $\begin{array}{l}.104 \\
.083 \\
.294\end{array}$ & $\begin{array}{l}.182 \\
.349\end{array}$ & $\begin{array}{l}1.745 \\
3.353 * * \\
6.086 * * *\end{array}$ \\
\hline Innovation & $\begin{array}{l}\text { Communication } \\
\text { Group decision making } \\
\text { Constant } \\
\mathrm{R}^{2}=.284, \mathrm{~F}=18.01 * * *\end{array}$ & $\begin{array}{l}.327 \\
.330 \\
.893\end{array}$ & $\begin{array}{l}.115 \\
.093 \\
.328\end{array}$ & $\begin{array}{l}.280 \\
.348\end{array}$ & $\begin{array}{l}2.847 * * \\
3.537 * * \\
2.719 * *\end{array}$ \\
\hline New idea & $\begin{array}{l}\text { Communication } \\
\text { Group decision making } \\
\text { Constant } \\
\mathrm{R}^{2}=.176, \mathrm{~F}=9.161 * * * \\
\end{array}$ & $\begin{array}{l}.273 \\
.271 \\
1.118\end{array}$ & $\begin{array}{l}.144 \\
.113 \\
.386\end{array}$ & $\begin{array}{l}.214 \\
.269\end{array}$ & $\begin{array}{l}1.902 \\
2.387 * \\
2.895^{* *}\end{array}$ \\
\hline Satisfaction & $\begin{array}{l}\text { Communication } \\
\text { Group decision making } \\
\text { Constant } \\
\mathrm{R}^{2}=0.79, \mathrm{~F}=3.796^{*}\end{array}$ & $\begin{array}{l}.017 \\
.174 \\
2.325\end{array}$ & $\begin{array}{l}. .093 \\
.073 \\
.259\end{array}$ & $\begin{array}{l}.021 \\
.270\end{array}$ & $\begin{array}{l}.183 \\
2.375^{*} \\
8.961 * * *\end{array}$ \\
\hline
\end{tabular}

$\left(^{*}\right)$ is $\mathrm{p}<.05,(* *)$ is $\mathrm{p}<.01,(* * *)$ is $\mathrm{p}<.001$

Table 3. Regression Results for Qualitative Performance Measures under Collectivistic leaders

\begin{tabular}{|c|c|c|c|c|c|}
\hline Dependent Variables & Independent Variables in the Model & $\mathrm{B}$ & SEB & $\beta$ & $\mathrm{t}$ value \\
\hline Quality & $\begin{array}{l}\text { Communication } \\
\text { Group decision making } \\
\text { Constant } \\
\mathrm{R}^{2}=.380, \mathrm{~F}=19.652^{* * *}\end{array}$ & $\begin{array}{l}.175 \\
.394 \\
1.395\end{array}$ & $\begin{array}{l}.094 \\
.080 \\
.297\end{array}$ & $\begin{array}{l}.197 \\
.518\end{array}$ & $\begin{array}{l}1.863 \\
4.905 * * * \\
4.691 * * *\end{array}$ \\
\hline Service & $\begin{array}{l}\text { Communication } \\
\text { Group decision making } \\
\text { Constant } \\
\mathrm{R}^{2}=.317, \mathrm{~F}=15.097^{* * *}\end{array}$ & $\begin{array}{l}.192 \\
.383 \\
1.458\end{array}$ & $\begin{array}{l}.106 \\
.091 \\
.339\end{array}$ & $\begin{array}{l}.198 \\
.461\end{array}$ & $\begin{array}{l}1.806 \\
4.202 * * * \\
4.306 * * *\end{array}$ \\
\hline Innovation & $\begin{array}{l}\text { Communication } \\
\text { Group decision making } \\
\text { Constant } \\
\mathrm{R}^{2}=.267, \mathrm{~F}=12.204 * * * \\
\end{array}$ & $\begin{array}{l}.339 \\
.321 \\
.902\end{array}$ & $\begin{array}{l}.129 \\
.110 \\
.403\end{array}$ & $\begin{array}{l}.296 \\
.328\end{array}$ & $\begin{array}{l}2.625 * \\
2.906 * * \\
2.237 *\end{array}$ \\
\hline New idea & $\begin{array}{l}\text { Communication } \\
\text { Group decision making } \\
\text { Constant } \\
\mathrm{R}^{2}=.173, \mathrm{~F}=6.776^{* *}\end{array}$ & $\begin{array}{l}.304 \\
.238 \\
1.103\end{array}$ & $\begin{array}{l}.154 \\
.122 \\
.452\end{array}$ & $\begin{array}{l}.247 \\
.244\end{array}$ & $\begin{array}{l}1.972 \\
1.953 \\
2.439^{*}\end{array}$ \\
\hline Satisfaction & $\begin{array}{l}\text { Communication } \\
\text { Group decision making } \\
\text { Constant } \\
\mathrm{R}^{2}=.125, \mathrm{~F}=4.729^{*}\end{array}$ & $\begin{array}{l}-.033 \\
.228 \\
2.391\end{array}$ & $\begin{array}{l}.094 \\
.076 \\
.290\end{array}$ & $\begin{array}{l}.044 \\
.367\end{array}$ & $\begin{array}{l}-.353 \\
2.975 * * \\
8.234 * * *\end{array}$ \\
\hline
\end{tabular}

$(*)$ is $\mathrm{p}<.05,(* *)$ is $\mathrm{p}<.01,(* * *)$ is $\mathrm{p}<.001$ 
Table 4. Regression Results for Qualitative Performance Measures under Individualistic Leaders

\begin{tabular}{|c|c|c|c|c|c|}
\hline Dependent Variables & $\begin{array}{l}\text { Independent Variables In } \\
\text { the Model }\end{array}$ & B & SEB & $\beta$ & t value \\
\hline Quality & $\begin{array}{l}\text { Communication } \\
\text { Group decision making } \\
\text { Constant } \\
\mathrm{R}^{2}=.177, \mathrm{~F}=2.048\end{array}$ & $\begin{array}{l}.217 \\
.089 \\
2.044\end{array}$ & $\begin{array}{l}.171 \\
.117 \\
.419\end{array}$ & $\begin{array}{l}.302 \\
.182\end{array}$ & $\begin{array}{l}1.269 \\
.764 \\
4.882 * * *\end{array}$ \\
\hline Service & $\begin{array}{l}\text { Communication } \\
\text { Group decision making } \\
\text { Constant } \\
\mathrm{R}^{2}=.189, \mathrm{~F}=2.104 \\
\end{array}$ & $\begin{array}{l}.467 \\
.032 \\
1.607\end{array}$ & $\begin{array}{l}.288 \\
.177 \\
.654\end{array}$ & $\begin{array}{l}.409 \\
.045\end{array}$ & $\begin{array}{l}1.622 \\
.179 \\
2.458^{*}\end{array}$ \\
\hline Innovation & $\begin{array}{l}\text { Communication } \\
\text { Group decision making } \\
\text { Constant } \\
\mathrm{R}^{2}=.452, \mathrm{~F}=7.005^{* *}\end{array}$ & $\begin{array}{l}.478 \\
.371 \\
.292\end{array}$ & $\begin{array}{l}.265 \\
.180 \\
.660\end{array}$ & $\begin{array}{l}.366 \\
.418\end{array}$ & $\begin{array}{l}1.803 \\
2.058 \\
.442\end{array}$ \\
\hline New idea & $\begin{array}{l}\text { Communication } \\
\text { Group decision making } \\
\text { Constant } \\
\mathrm{R}^{2}=.246, \mathrm{~F}=2.282 \\
\end{array}$ & $\begin{array}{l}.647 \\
.233 \\
.337\end{array}$ & $\begin{array}{l}.502 \\
.355 \\
1.109\end{array}$ & $\begin{array}{l}.365 \\
.186\end{array}$ & $\begin{array}{l}1.290 \\
.657 \\
.304\end{array}$ \\
\hline Satisfaction & $\begin{array}{l}\text { Communication } \\
\text { Group decision making } \\
\text { Constant } \\
\mathrm{R}^{2}=.010, \mathrm{~F}=.077\end{array}$ & $\begin{array}{l}.129 \\
-.038 \\
2.339\end{array}$ & $\begin{array}{l}.340 \\
.217 \\
.699\end{array}$ & $\begin{array}{l}.123 \\
-.056\end{array}$ & $\begin{array}{l}.381 \\
-.173 \\
3.348 * *\end{array}$ \\
\hline
\end{tabular}

$(*)$ is $\mathrm{p}<.05,(* *)$ is $\mathrm{p}<.01,(* * *)$ is $\mathrm{p}<.001$

Table 5. Regression Results for Quantitative Performance Measures for the Total Sample $(\mathrm{N}=66)$

\begin{tabular}{|c|c|c|c|c|c|}
\hline Dependent Variables & $\begin{array}{l}\text { Independent Variables In } \\
\text { the Model }\end{array}$ & B & SEB & $\beta$ & $\mathrm{t}$ value \\
\hline Profit growth & $\begin{array}{l}\text { Communication } \\
\text { Group decision making } \\
\text { Constant } \\
\mathrm{R}^{2}=0.16, \mathrm{~F}=.420 \\
\end{array}$ & $\begin{array}{l}-103.794 \\
138.772 \\
187.179\end{array}$ & $\begin{array}{l}219.234 \\
154.520 \\
685.647\end{array}$ & $\begin{array}{l}-.069 \\
.131\end{array}$ & $\begin{array}{l}-.473 \\
.898 \\
.273\end{array}$ \\
\hline Return on investment & $\begin{array}{l}\text { Communication } \\
\text { Group decision making } \\
\text { Constant } \\
\mathrm{R}^{2}=.124, \mathrm{~F}=3.673^{*}\end{array}$ & $\begin{array}{l}-.079 \\
.049 \\
.224\end{array}$ & $\begin{array}{l}.034 \\
.024 \\
.105\end{array}$ & $\begin{array}{l}-.323 \\
.284\end{array}$ & $\begin{array}{l}-2.347^{*} \\
2.062^{*} \\
2.139^{*}\end{array}$ \\
\hline Sales growth & $\begin{array}{l}\text { Communication } \\
\text { Group decision making } \\
\text { Constant } \\
\mathrm{R}^{2}=.046, \mathrm{~F}=1.226\end{array}$ & $\begin{array}{l}-142.212 \\
-128.602 \\
997.401\end{array}$ & $\begin{array}{l}184.500 \\
127.004 \\
571.685\end{array}$ & $\begin{array}{l}-.112 \\
-.148\end{array}$ & $\begin{array}{l}-.771 \\
-1.013 \\
1.745\end{array}$ \\
\hline
\end{tabular}

$(*)$ is $\mathrm{p}<.05,(* *)$ is $\mathrm{p}<.01,(* * *)$ is $\mathrm{p}<.001$

Table 6. Regression Results for Quantitative Performance Measures under Collectivistic Leaders $(N=41)$

\begin{tabular}{|l|l|l|l|l|l|}
\hline Dependent Variables & Independent Variables In the Model & $\mathrm{B}$ & $\mathrm{SEB}$ & $\beta$ & $\mathrm{t}$ value \\
\hline Profit growth & Communication & -140.387 & 200.704 & -.109 & -.699 \\
& Group decision making & 310.735 & 147.560 & .328 & $2.106^{*}$ \\
& Constant & -217.144 & 691.214 & & -.314 \\
& $\mathrm{R}^{2}=.103, \mathrm{~F}=2.243$ & & & & \\
\hline Return on investment & Communication & -.110 & .038 & -.421 & $-2.899^{* *}$ \\
& Group decision making & .062 & .028 & .323 & $2.226^{*}$ \\
& Constant & .297 & .131 & & $2.265^{*}$ \\
& $\mathrm{R}^{2}=.220, \mathrm{~F}=5.501^{* *}$ & & & & \\
\hline Sales growth & Communication & 173.932 & 162.948 & .176 & 1.067 \\
& Group decision making & -6.456 & 115.492 & -.009 & -.056 \\
& Constant & -454.641 & 554.608 & & .417 \\
& $\mathrm{R}^{2}=.030, \mathrm{~F}=.590$ & & & & \\
\hline
\end{tabular}

$(*)$ is $\mathrm{p}<.05,(* *)$ is $\mathrm{p}<.01,(* * *)$ is $\mathrm{p}<.001$ 
Table 7. Regression Results for Quantitative Performance Measures under Individualistic Leaders $(\mathrm{N}=25)$

\begin{tabular}{|l|l|l|l|l|l|}
\hline Dependent Variables & $\begin{array}{l}\text { Independent Variables In } \\
\text { the Model }\end{array}$ & $\mathrm{B}$ & $\mathrm{SEB}$ & $\beta$ & $\mathrm{t}$ value \\
\hline Profit growth & Communication & 1791.576 & 1126.938 & .709 & 1.590 \\
& Group decision making & -1187.657 & 616.696 & -.859 & -1.926 \\
& Constant & -1350.310 & 2171.543 & & -.622 \\
& $\mathrm{R}^{2}=.293, \mathrm{~F}=1.865$ & & & & \\
\hline Return on investment & Communication & .149 & .075 & .877 & 1.990 \\
& Group decision making & -.071 & .041 & -.760 & -1.725 \\
& Constant & -.131 & .145 & & -.908 \\
& $\mathrm{R}^{2}=.310, \mathrm{~F}=2.020$ & & & -1.437 \\
\hline Sales growth & Communication & -1132.697 & 788.322 & -.536 & -.563 \\
& Group decision making & -243.034 & 431.395 & -.210 & $2.949 *$ \\
\hline & Constant & 4479.307 & 1519.051 & & \\
\hline
\end{tabular}

$\left(^{*}\right)$ is $\mathrm{p}<.05,(* *)$ is $\mathrm{p}<.01,\left({ }^{* * *}\right)$ is $\mathrm{p}<.001$ 